\title{
Social Practices of Using War Memorials in Russia: A Comparison between Mamayev Kurgan in Volgograd and Poklonnaya Gora in Moscow
}

\author{
Elizaveta Polukhina \\ Associate Professor, Faculty of Social Sciences, National Research University Higher School of Economics \\ Address: Myasnitskaya str. 20, 101000 Moscow, Russian Federation \\ E-mail: epolukhina@hse.ru \\ Alexandrina Vanke \\ Vide-Dean, Sociological Faculty, State Academic University for Humanities \\ Address: Maronovsky Pereulok 26, 119049 Moscow, Russian Federation \\ E-mail: alexandrina.vanke@gmail.com
}

\begin{abstract}
This paper presents the results of research into the social practices of using memorials dedicated to the Second World War in post-soviet Russia. The authors introduce a comparative analysis of two case studies. They examine Poklonnaya Gora, ${ }^{1}$ located in Moscow, which is a site of memory (lieux de memoir), according to Pierre Nora, where there was no real fighting during the Battle of Moscow in 1941-1942. This is contrasted with Mamayev Kurgan, located in Volgograd, which is a site of remembrance (lieux de souvenir), according to Aleida Assman, where violent fighting took place during the Battle of Stalingrad in 1942-1943. The authors describe in detail the spatial infrastructure of both memorials and make a classification of the practices in relation to their use, including commemorative, political, leisure, religious, and infrastructure-related social practices exercised by different groups of social agents. The authors conclude that Poklonnaya Gora is a universal memorial relaying a monological heroic discourse, whereas Mamayev Kurgan reproduces the same triumphant discourse, yet twisted through the local context of interaction between the local authorities and the city's communities.
\end{abstract}

Keywords: war memorials, space of war memorials, use of war memorials, social practices, Poklonnaya Gora, Mamayev Kurgan, Russia

\section{Introduction}

Interaction with war memorials dedicated to the Second World War (WWII) and built in the countries formerly constituting the Soviet Union is a subject for increasing discussion and research in modern Russia and beyond. Sociological studies on interactions with war memorials are based on the metaphor of "site," which refers to the corresponding geographical and time coordinates, and events. Any war memorial has a certain spatial location, and on memorial days various activities are undertaken around it, varying from

(C) Elizaveta Polukhina, 2015

(C) Alexandrina Vanke, 2015

(C) Russian Sociological Review, 2015

DOI: $10.17323 / 1728-192 \mathrm{X}-2015-4-115-128$

1. Note: literally, the Bow Down Hill, also referred to as the Hill of Respectful Salutation or the Worshipful Submission Hill. 
annual Victory Day ${ }^{2}$ celebrations to the laying of flowers and wreaths. A memorial is located within a site that serves as a point of transition and convergence of different dimensions - the past and the present, space and time, public festivities and everyday life.

Studying the practices of interactions with war memorials, we turn to two notions that converge in the metaphor of site. The first of them is "site of memory" (lieux de memoir), first introduced by Nora. This term implies sites turned into covenants of collective memory for a society or social groups: "Numerous sites of memory ... exist because there is no longer any social group memory" (Nora, 1999: 17); they appear when the live communicative memory of eyewitnesses gives place to cultural memory (Vanke, Polukhina, 2014: 37). Studies on sites of memory are linked to the research of both discursive and material traces and physical objects, including war memorials, the functions they perform, and the ways they are referred to in different contexts. The second concept is the "site of remembrance" (lieux de souvenir), which means "a site meaningful for someone's individual biography" (Assmann, 2014: 236). In contrast to an abstract space for human planning, creation and exploration, a site of remembrance is "a specific space where people have already performed some activities" (Assmann, 2014: 237-238). Human activities on sites of remembrance are linked to human fates, emotional experiences and recollections which are projected through monuments (Ibid.: 236). An example is Mamayev Kurgan, commemorating the Battle of Stalingrad, where real combat operations took place, with the recollections of eyewitnesses differing from the views of those who have learned about those events from other sources.

According to Debrè, "praising the 'sites of memory' higher than the communities of people capable of memorizing things, and making these sites independent of these communities is tantamount to making a fetish out of a building and, if you will, to separating a habitat from the habitation therein, or a body from the soul" (Debrè, 2009: 25). This means that it is impossible to study monuments and memorials in isolation from the surrounding communities and publics which form and are formed by the changing configurations of interactions, meanings and emotions that surround them. Therefore, we use the case study method for investigating the practices of using WWII memorials as sites of memory and sites of remembrance, that is, a comparative study of social phenomena in the context of the real course of events and situations, whereby the boundaries between the phenomenon and the context are blurred (Yin, 1994: 13). A case study includes the following methods of collecting empirical data: social ethnography, overt observation, interviews and analysis of documents (Polukhina, 2013: 7).

We have selected two memorial complexes, which are very significant for Russians and enjoy government support, because the social practices exercised in these spaces clearly demonstrate the general attitudes to major war memorials in contemporary Russia. The cases differ from each other by their geographical location, as the principle of capital city/regional context was used for their selection; however, the cases chosen are similar in terms of devotion, scope and the grandiosity of the architectural concept.

2. Victory Day is celebrated in Russia on the 9 th of May and is the commemoration of the victory in the Great Patriotic War (1941-1945). 
Empirical data were collected at Poklonnaya Gora and Mamayev Kurgan simultaneously on May 9, 2014, ${ }^{3}$ and non-simultaneously on other days, which made it possible to compare the social use of the two memorials during Victory Day celebrations and in everyday life, in the capital city and in the region. The comparison parameters were the spatial (infra)structures of the memorial complexes and the social practices exercised on the sites.

The empirical database of the project consisted of 21 street interviews with visitors to both memorials, two expert interviews with employees of the museums located on the premises of the complexes in question, seven sessions of overt observation and more than 500 photographs. Chosen for observation were holidays, weekdays and weekends; mornings, afternoons and evenings; sunny, rainy and frosty weather. The results were recorded in a field diary in thick description. The collection of field data at Poklonnaya Gora took place on May 9, 2013, ${ }^{4}$ February 23, March 20 and May 9, 2014, and from May 1 through May 20, 2014 at Mamayev Kurgan.

\section{Spatial (Infra)structure of the Memorials}

The Memorial Complex at Mamayev Kurgan is a monument to the Heroes of the Battle of Stalingrad and a national symbol of Russia. ${ }^{5}$ It is located on a high hill in the city of Volgograd (formerly Stalingrad, and earlier known as Tsaritsyn) with a population of around 1 million in 2014. Its central 85-meter-high statue named "Your Motherland Is Calling!" can be seen from almost anywhere in Volgograd, with the local people regarding this statue as a symbol of their city and the pride of the Volgograd Region. Its significance it can be compared to the Statue of Liberty in New York $(46 \mathrm{~m})$ and the Statue of Christ the Redeemer in Rio de Janeiro $(36 \mathrm{~m})$. This monument embodies the historical memory of WWII (Semenenko, 2008: 14).

Mamayev Kurgan is a site of remembrance, associated with the war-the grief and heroism of the victorious people. In terms of landscape, Mamayev Kurgan is a hill located in the central part of the city. During the 1942-1943 Battle of Stalingrad, a 200-day long battle took place on the hill. According to the official view (Krivosheyev, 2001), the Battle of Stalingrad was the turning point in the war, after which the Soviet Army gained the initiative. The monument to the Heroes of the Battle of Stalingrad was conceived as a space demonstrating the greatness of the people's heroism, the bitterness of the losses and the significance of the victory on a global scale. The memorial was designed as a great, powerful and perpetual complex. The work on the project began as early as in 1948 and

3. The poly-local ethnography method is used by Gabowitsch (2015) in his studies of Soviet war memorials in Central and Eastern Europe.

4. Field materials at Poklonnaya Gora were collected in 2013 by one of the authors under the project "The Monument and the Holiday: May 9 Celebrations and the Interaction of Soviet War Monuments with Local Communities in the Soviet Military Block Heir Countries," supported by the Center for French and Russian Research and Memorial Society.

5. According to All-Russia Public Opinion Research Center (WCIOM) as of September 2013, Mamayev Kurgan was regarded as a national symbol by $12 \%$ of the Russians (WCIOM, 2013). 
the foundation stone laying ceremony was held on February 2, 1958. Then mine sweeping operations were conducted at Mamayev Kurgan.

The opening took place on October 15, 1967, and was attended by high-ranking military and civilian officials. During the ceremony, an Eternal Flame was lit by Leonid Brezhnev. The statue "Your Motherland Is Calling!" was listed in the Guinness Book of Records as the world's largest sculpture; it weighs around 8 ooo tons and has a height of 85 meters. The memorial complex was designed by a team headed by sculptor Yevgeniy Vuchetich and architect Yakov Byelopolsky, both of them also having taken part in creating Berlin's Treptow Park complex. The monument site area is 26 hectares.

Around 35000 people were buried on the hill of Mamayev Kurgan, though many sources estimate the number of those who died during the Battle of Stalingrad as higher. "Do you know what kind of place this is?! There was a sea of blood here, grass and trees did not grow here for twenty years after the end of the war. Thousands were killed daily!" (a female attendant at the Stalin Museum, ${ }^{6}$ Mamayev Kurgan, 05.08.2014).

The scale of casualties is also depicted in a short story by Victor Nekrasov, a writer and participant of the Battle of Stalingrad:

\begin{abstract}
"And the mound [kurgan] on which I was fighting and where my soldiers were laying antipersonnel land mines into the frozen ground was called 'Mamayev Kurgan'. For five months blood was being shed there, instantly being frozen. When several years later, seven, to be correct, I happened to be there, it was still entirely covered with skulls and bones as the ground had been washed away by rain. . . Everything is the biggest in this country. The mountains, rivers, dams, rockets and the Party. And this is the world's biggest monument. One toe of this monstrous woman is twice or even three times as large as an ordinary man. And all around there are dozens of grandiose sculptures, symbols, allegories and a pool, and above it there is a half-naked warrior with a submachine gun and the resolute face of Marshal Chuykov." (Nekrasov, 2005)
\end{abstract}

Victory Park at Poklonnaya Gora, along with the Eternal Flame in Aleksandrovsky Garden, is considered by Russians as the most significant memorial complex to commemorate the victory in WWII in Moscow. Poklonnaya Gora holds a certain place in the mentality of Muscovites and has triumphal, heroic and religious connotations. As it is located in the western part of the city, there was no fighting on Poklonnaya Gora itself during the German offensive on Moscow in 1941-1942. In 1942, however, it was proposed that a memorial complex be built there in honor of the heroic struggle of the Soviet people during the war. At the same time, the Union of Architects of the USSR announced a contest for the best design of the memorial complex (The History of Creating the Museum, 2014), but its implementation was suspended. Only in 1958, under the Khrushchev administration, was a memorial headstone laid at Poklonnaya Gora with the inscription: "Here will stand a monument to the victory of the Soviet people in the Great Patriotic War of 1941-1945."

6. More details on the Stalin Museum at Mamayev Kurgan are available at: http://vetert.ru/rossiya/volgo$\mathrm{grad} / \mathrm{sights} / 337$-muzej-stalina.php (accessed 9 January 2015). 


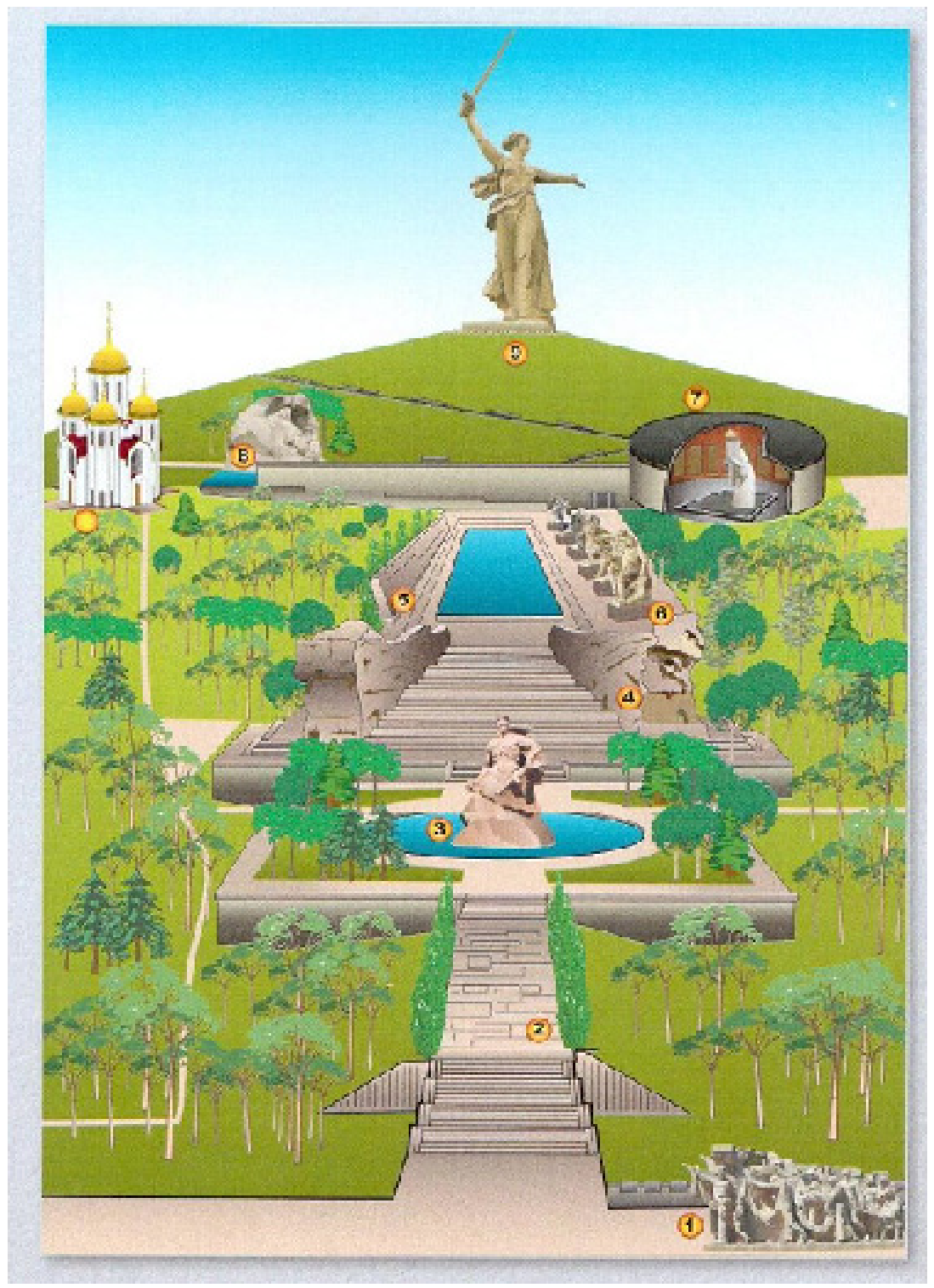

Figure 1. Layout of the Mamayev Kurgan Memorial Complex in Volgograd7

7. This layout was taken from the book "Mamayev Kurgan: The Main Height of Russia" (Volgograd: Panorama, 2013: 107). The elements of the Memorial Complex are: (1) an entrance square with the introductory composition "The Memory of the Generations"; (2) a Lombardy poplar lined avenue; (3) Stoyat' Nasmiert' (Die in the Last Ditch) Square with a giant warrior hero statue; (4) symbolic ruined walls; (5), (6) the Square of Heroes with six sculpture groups; (7) a Hall of Glory with a monumental bas-relief; (8) the Square of Grief; (9) The main monument "Your Motherland Is Calling!"; (10) All Hallows Church. 
Victory Park, completed in 1995 according to Zurab Tsereteli's design, is a site of memory, which accumulates cultural heritage in the form of monuments, artifacts, material objects and discursive traces (Nora, 1998), serving to relay the national memory of the war.

Victory Park is located on a natural elevation, a slightly sloping hill in the Western Administrative District of Moscow, which was named "Poklonnaya Gora" from the word "to bow," semantically referring to the ritual of worshiping the city, the churches, the guests or the gods, who, according to the myth, abide high on the top of Mount Olympus, or in heaven (Moldovan, 2011: 301). Perhaps, it brings about associations with the "holiness" of the hill which symbolically and geographically immortalizes the memory about the war. Victory Park is framed by Minskaya Street and Kutuzovsky Prospekt, the latter rolling into Mozhaiskoye Shosse. It has an area of 135 hectares. The area of Victory Park is filled with commemorative items of different kinds, with new ones being added from time to time.

The two war memorials are organized in a similar manner. Both are located on elevations, and are surrounded by designations and memorable spots related to military themes. Both offer similar semantic paths that can be followed and "read" by the visitor. The size of the memorials and their multi-kilometer length tells the visitor about the grandeur of the memorable events and their importance to the national history. The long walkway, the number of stairs and steps in the "paths of memory" symbolize the hard road travelled by our predecessors. The emphasis is reinforced by war sculptures and inscriptions, symbolizing both heroism, and grief.

The memorials include small bodies of water and waterways, next to the pathways leading to the main monuments. These waterways are a reminder of the "tears" shed by mourning mothers and other people for their loved ones. On the way to the main statues, there is an Eternal Flame burning as if to perpetuate the memory. The main peak of the memorials is a majestic female statue, personifying the Victory. Both memorial complexes hold WWII museums and Orthodox churches.

Mamayev Kurgan is a single-event memorial, dedicated exclusively to the Battle of Stalingrad, whereas Poklonnaya Gora, by contrast, commemorates many wars and tragic events, such as WWI, WWII, the Afghan War, and the Holocaust. The Mamayev Kurgan sculptures were designed in the traditional manner of the time, in the style of socialist realism. They demonstrate human abilities as the backbone of the victory. The sculpture ensemble retains socialist realism features expressed through the national spirit, heroism and the proximity to historic events. The multi-event war memorial at Poklonnaya Gora was designed in the abstractionist style with its eclecticism and disproportion and a combination of secular and religious features. In addition to an Orthodox church, Victory Park also houses a mosque and a synagogue. It would be hard imagine such buildings at Mamayev Kurgan. Thus, while Mamayev Kurgan is the site of a single great battle which laid the foundation for victory in WWII, Poklonnaya Gora is a place reminding of war-related grief and sorrows and appealing for solidarity between various social groups. 


\section{Memorial Interaction Practices}

Using overt observation performed at Mamayev Kurgan and Poklonnaya Gora during the May 9 and February 23 celebrations, and based on the monitoring of these memorials on weekdays, we classify the activities undertaken by different social agents with regard to the monuments. In other words, we can single out the types of practices used in interaction with the memorials by applying the following binary oppositions: capital city/ region, site of remembrance/site of memory, official/individual; and single out the following series of practices: commemorative, political, leisure, religious, and infrastructure maintenance.

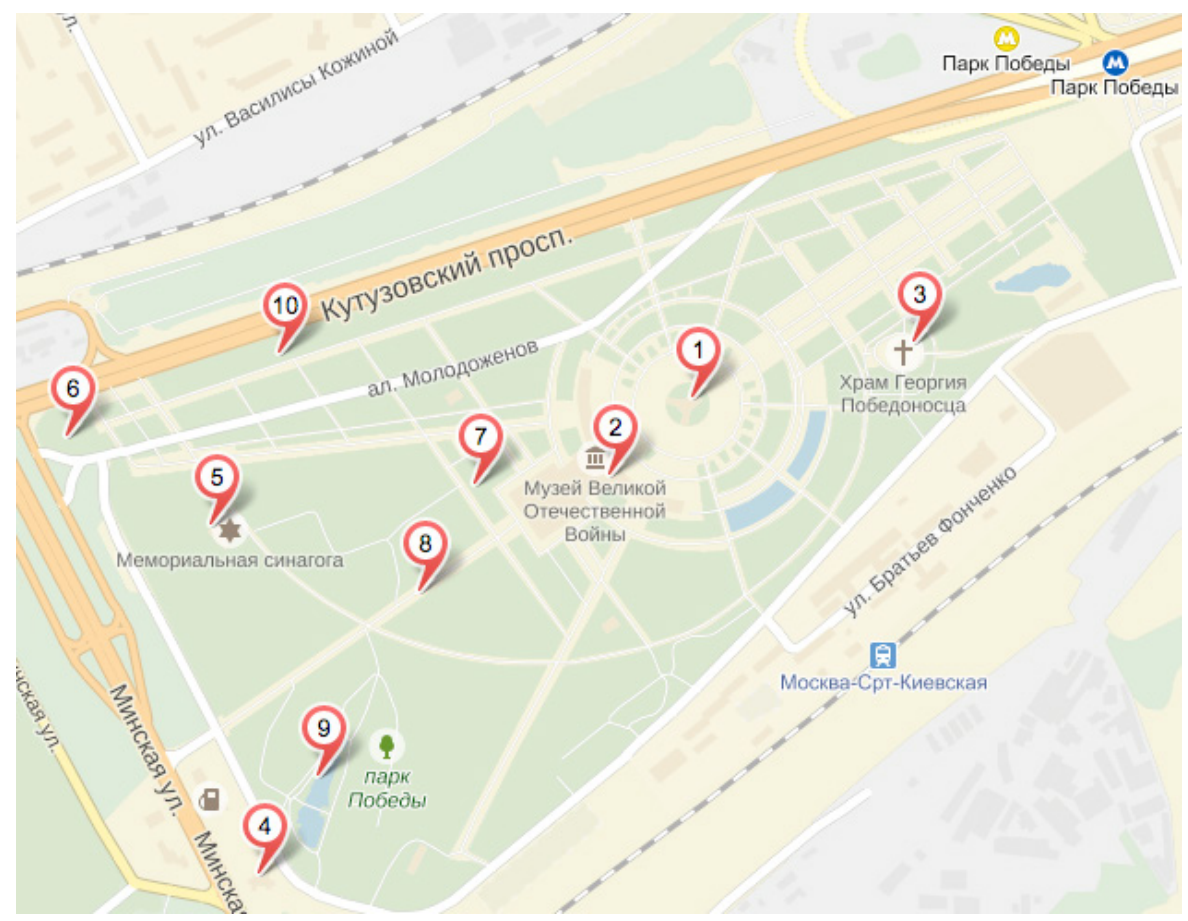

Figure 2. Layout of Victory Park at Poklonnaya Gora in Moscow ${ }^{8}$

8. Components of Victory Park are: (1) Victory Obelisk, 141.8 meters high, representing the 1,418 days of the war, was erected in 1995 and is now among the tallest monuments of Russia; (2) the Museum of the Great Patriotic War of 1941-1945, established in 1986; (3) St. George the Dragon Slayer Church, built by the Moscow Government in 1995; (4) a Memorial Mosque, built in 1997 in memory of the Muslims killed during the war; (5) a Memorial Synagogue and the Holocaust Memorial Museum, built with the support of the Russian Jewish Congress in 1998; (6) the Monument to the Defenders of the Russian Land, constructed in 1997; (7) a sculpture composition "The Tragedy of the Peoples" in memory of the Holocaust victims, built in 1997; (8) a monument "To the Spaniards Fallen in the Great Patriotic War of 1941-1945," dated 2001; (9) a Naval Weapons Exhibition; (10) an Outdoor Weapons and Military Equipment Exhibition. 


\section{Commemorative Practices}

These make up a set of secular memorial and ritual interactions. Kolyagina and Konradova (2015: 137) write that while in the Soviet period May 9 was celebrated en famille, today we can see a tendency towards extended public practices of Victory Day celebrations that more and more take place in streets and squares. On the one hand, these practices are similar at both memorials. They include laying flowers, greeting veterans and giving them presents, singing wartime songs, seeing war movies, staging outdoor theatrical performances and concerts (for more detailed information on the repertoire of Victory Day celebration social practices at Poklonnaya Gora see: Vanke, 2015: 216-217). Huge bouquets of flowers can be seen at practically every sculpture at Mamayev Kurgan and at some monuments of Poklonnaya Gora on Victory Day. In both cases, flowers and wreaths are normally laid at the Eternal Flame; many of them can be found around the central objects, some in the peripheral areas. When answering our question during a street interview at Poklonnaya Gora one of the interviewees enumerated the following actions: "We presented flowers [to veterans], postcards, bars of chocolate, sweets, and passed them a greeting from our Most Holy Patriarch" (a 20-year-old female, Poklonnaya Gora, 05.09.2014).

On the other hand, commemorative practices have a number of inner distinctions due to the fact that Mamayev Kurgan is a site of remembrance while Poklonnaya Gora is a site of memory; this imposes certain restrictions on the rules of behavior on these sites. Both the authorities and the public have well-established ideas about the norms and ethics of the attitude towards and the use of Mamayev Kurgan as a site of remembrance, whose historic background is a significant part of national history. Apart from the monuments and chapels, this attitude is extended to the common graves where the soldiers who died in 1942-1943 were buried, and many people come there to commemorate the fallen warriors.

Being a place of memory, Poklonnaya Gora unites cultural reminiscences of several wars. Its area is inundated with monuments but the public does not catch sight of many of them. Therefore, the site becomes a point of emanation for official victory discourses and a center of attraction for ordinary people, which in the mass media discourse is usually referred to as "popular." Poklonnaya Gora is located on the periphery of Moscow, and for this reason wreath-laying ceremonies are usually conducted at the Kremlin Wall where the Eternal Flame is burning (for more details about this ritual see Vanke, Polukhina, 2014: 48). On the contrary, Mamayev Kurgan is located in the symbolic center of Volgograd, due to which laying flowers at the Eternal Flame by the officials has become a tradition for this site.

\section{Political Practices}

These have ideological nuances and suggest activities such as participation in official mass marches and rallies, patriotic events. 
On May 9, an official march at Mamayev Kurgan with participants from political parties, and municipal and regional authorities takes place in the morning. It is telecast and flags representing different political parties and government organizations are visible. Ordinary visitors and the marching groups seldom mix with each other. It should be noted that sometimes these political attributes provoke indignation among people: "Found a good place to wave your [party] flags?!" (a 28-year-old male, Mamaev Kurgan, 05.09.2014). The limits to ethical norms may be determined by studying conflict situations. They occur due to the fact that such places as Mamayev Kurgan and the monument "Your Motherland Is Calling!" have different purposes for official authorities, represented by people from the city administration and the regional branches of political parties, on the one hand, and for the broader public and various social groups, on the other hand. In 2014, Mamayev Kurgan was mentioned by the press in connection with meetings in support of the integration of the Crimea (Interfax Russia, 2014).

Mass patriotic events also take place at Poklonnaya Gora. For example, in February 2012 an "anti-orange rally" was held there (Kalk, 2012); in September 2013, a rally in support of the newly elected Moscow Mayor Sergei Sobyanin was organized; and on May 9, 2014, a symbolic event called "The Immortal Regiment" march took place. The participants of the latter mass event broke into columns according to the number of Moscow's administrative districts. Each district was represented by its residents who came to Poklonnaya Gora with photographs of their relatives who had taken part in the war. No conflict situations between the authorities and the public have ever happened at Poklonnaya Gora, for this site relays such a consistent and generally accepted narrative on WWII that it is not perceived by both pro-government and opposition activists as a venue for confrontation. Instead, this place seems to be totally appropriated and controlled by the authorities. That is why it relays a monological memory about the war and rules out any opportunities for public debate (Vanke, 2015: 212).

\section{Leisure Practices}

These are applicable in the context of recreational opportunities offered by the two memorials which are traditionally considered as popular areas for recreation and tourism and as public use areas at the same time.

Poklonnaya Gora attracts a large number of city people in spring and summer due to its landscape, the design of its parkland, and the availability of lawns, paths and fountains. For the people of Volgograd, Mamayev Kurgan is also an improved "green" park and a site for ceremonies and rituals, such as newlyweds' visits, for example: "Almost all newlyweds in this city celebrated here on the kurgan; even if the photo shoot is in another place, the newlyweds will surely come here to lay flowers at the tomb, at the Eternal Flame" (a male photographer, resident of Volgograd, 05.09.2014). The practices of photo shoots and laying flowers at the Eternal Flame by newlyweds are also typical for Poklonnaya Gora, where wedding motorcades go along the Avenue of Brides. 
Mamayev Kurgan's area is significantly commercialized. It abounds in stalls selling merchandise such as postcards, and souvenirs. The symbol "Your Motherland Is Calling!" is well replicated and appears on magnets, T-shirts, mugs, beer glasses, plastic bags and ballpoint pens. As for Poklonnaya Gora, the number of food and beverages stalls increases greatly during the Victory Day celebration period (May 7-10). On weekdays, there are no street markets in the square because all the souvenirs are sold in the WWII Museum building.

\section{Religious Practices}

These include participation in public prayers, memorial services and mass religious processions. The Orthodox Way of the Cross processions are organized both at Poklonnaya Gora and Mamayev Kurgan, which point at the domination of one single religion within the spaces of the two memorials and its intertwining with the generally accepted WWII narrative.

At the same time, there is an Orthodox church, a mosque and a synagogue in Victory Park which creates both a configuration and a pre-condition for people from different religious and ethnic groups to mix together in the same place and at the same time (on May 9, for example). In spite of the fact that religious events at Mamayev Kurgan have been taken place since $1996^{9}$, the only functioning Orthodox church there now is the one opened in 2005, which minimizes any interaction between Volgograd permanent residents and migrant workers who do not consider this place to be theirs.

A different situation is observed at Poklonnaya Gora, where various rituals are carried out at the mosque. This mosque is becoming more and more important for Moscow Muslims, and especially for migrant workers visiting it during religious holidays. The synagogue at Poklonnaya Gora makes it possible to exercise not just religious practices, but also commemorative and cultural practices, because, in addition to being a temple, it serves as a museum and an exhibition center. The staff conduct tours and arrange thematic exhibitions.

\section{Maintenance Practices}

At these two memorials, infrastructure maintenance practices and mass events, varying from festivities to rallies, are usually organized by municipal authorities, less often by city people engaged in volunteer cleaning and landscape maintenance. For example, every year the celebration of the Victory Day on May 9 at Poklonnaya Gora is organized and supported by workers of various municipal agencies, the Russian Union of Rescuers, the Russian Emergencies Ministry, paramedics, retail outlets and police officers, as well as by volunteers, members of student unions and patriotic organizations.

At the same time, the authorities regard both Mamayev Kurgan and Poklonnaya Gora as sites to be properly guarded, secured and maintained, and as important political tools.

9. Way of the Cross Procession 200o. Available at: http://www.youtube.com/watch?v=jo8nUoKS984 (accessed 12.25.2014). 
The public sees them as "sacred" and "popular" places, places that are common and public, places that deserve to be honored and carefully maintained, with open discussions to be held on all issues concerning their future. Since the mid-201os, the government's policy has been aimed at maintaining their infrastructure and their maximum possible use-not only on May 9, but on other days as well. Significant funds are allocated annually for their maintenance.

\section{Conclusion}

In spite of the different socio-historical contexts in which the Memorial Complex to the Heroes of the Battle of Stalingrad on Mamayev Kurgan in Volgograd (1967) and Victory Park on Poklonnaya Gora in Moscow (1995) were created, both memorials are similar in terms of their thematic scope and spatial scale: they relay a consistent and triumphant discourse on the war. Their central monuments, the Victory Obelisk and the statue "Your Motherland Is Calling!" embody feminine images - the first of the ancient Greek goddess of victory Nike and the second of the Mother-Motherland, the latter being a personified image of Russia. On both sites, Museums of the Great Patriotic War and Eternal Flames serve as sense-making elements. Both sites accommodate religious temples and both memorial complexes have artificial waterworks.

Due to the differences in the reasons for creating these memorials, and in their geographic location (one in the capital, the other regional), these sites perform different functions and possess different meanings, which brings about different configurations of social activities. Poklonnaya Gora is a multi-event site of memory, semantically embracing several wars, whereas Mamayev Kurgan is a mono-event site of remembrance. In this regard, the connotative meanings of the two memorials differ as they appear in the local contexts of Victory Day celebrations, that is, in here-and-now situations.

With the help of a comparative analysis we have created a classification of the types of social activities. These include commemorative, political, leisure, religious and infrastructure-related practices that differ from each other in different contexts, viewed through the prism of such binary oppositions as capital city/regional, universal/local and official/public. Poklonnaya Gora is a universal memorial relaying a monological heroic discourse, whereas Mamayev Kurgan reproduces the same triumphant discourse, yet twisted through the local context of interaction between the local authorities and the city's communities.

All this makes it possible to conclude that two-way communication on war memorials between the authorities and society is difficult in contemporary Russia. It is irregular and sometimes vacuous, in contrast to the situation in Central and East European countries (Gabowitsch, 2015: 108) where the problems of rehashing the memory and reorganizing Soviet war memorials are the subject of public debate and, in some cases, these problems are settled by reaching a consensus between the authorities and society. 


\section{References}

Assmann A. (2014) Dlinnaya ten' proshlogo: memorial'naya kul'tura i istoricheskaya politika [The Long Shadow of the Past: Memorial Culture and Historical Policy], Moscow: Novoe literaturnoe obozrenie. (In Russian)

Debrè P. (2009) Vvedenie v medialogiyu [Introduction into Medialogia], Moscow: Praksis. (In Russian)

Gabowitch M. (2015) Pamyatnik i prazdnik: etnografiya Dnya Pobedy [The Monument and the Holiday: The Ethnography of the Victory Day]. Neprikosnovennyi zapas, no 3, pp. 93-111. (In Russian)

The History of Creating a Museum (2014). Unpublished document from the authors' archive.

Interfax Russia (2014) V Volgograde proshel miting v podderzhku zhitelei Kryma [A Meeting in Support of the Crimea People was Held in Volgograd]. Interfax Russia, March 4, 2014. Available at: http://www.interfax-russia.ru/South/news. asp?id=478416\&sec $=1671$ (accessed 20 December 2014). (In Russian)

Kalk A. (2012) "Kreativnaya” Bolotnaya i "narodnaya” Poklonnaya: vizual'nyi ryad mitingov v rossiiskikh SMI [The "Creative" Bolotnaya Square and the "Popular" Poklonnaya": A Visual Array of Meetings in the Russian Mass Media]. Laboratorium, no 2, pp. 164-172. (In Russian)

Kolyagina N., Konradova N. (2015) Den' Pobedy na Poklonnoi gore: struktura prostranstva i ritualy [Victory Day at Poklonnaya Gora: The Structure of the Space and the Rituals]. Neprikosnovennyi zapas, no 3, pp. 135-149. (In Russian)

Krivosheyev G. (2001) Rossiya i SSSR v voinakh XX veka: poteri vooruzhennykh sil: statisticheskoe issledovanie [Russia and the USSR in the 2 oth $^{\text {th }}$ Century Wars: Armed Forces Casualties: A Statistical Study], Moscow: Olma Press. (In Russian)

Moldovan A. (2011) Poklonnaya gora [Poklonnaya Gora]. Slovo i yazyk [Word and Language] (eds. I. Boguslavsky, L. Iodmin, L. Krysin), Moscow: Yazyki slavyanskikh kul'tur, pp. 298-306. (In Russian)

Nekrasov V. (2005) P.S. k "okopnoj pravde" [P. S. to the "Trench Truth"]. Nashe nasledie, no 73 , pp. 15-19. (In Russian)

Nora P. (1999) Problematika mest pamjati [The Issues of the Sites of Memory]. Frantsiyapyamyat' [France-Memory] (eds. P. Nora, M. Ousuf, J. de Puymeige), Moscow: Vinok; Saint-Peterburg: Stationary Office, pp. 17-50. (In Russian)

Polukhina E. (2013) Case-study kak issledovatel'skaja strategija [Case-study as a Research Strategy]. Case-study: obrazovatel'nyj $i$ issledovatel'skij opyt $v$ mezhdisciplinarnom kontekste [Case-Study: Educational and research Experience in the Interdisciplinary Context] (eds. E. Veretennik, D. Strekalova), Saint Petersburg: HSE, pp. 5-21. (In Russian)

Samyi vysokii monument Rossii [The Tallest Monument in Russia]. Kniga rekordov Rossii [The Book of Records of Russia]. Available at: http://knigarekordovrossii.ru/index. 
php/rekordy/arkhitektura/581-samyj-vysokij-monument-v-rossii.html (accessed 10 September 2015). (In Russian)

Semenenko I. (2008) Obrazy i imidzhi v diskurse natsional'noi identichnosti [Shapes and Images in the Discourse of National Identity]. Polis, no 5, pp. 7-18. (In Russian)

Vanke A. (2015) Landshafty pamyati: Park Pobedy na Poklonnoi gore v Moskve [Landscapes of Memory: Victory Park at Poklonnaya Gora in Moscow]. Neprikosnovennyi zapas, no 3, pp. 203-220. (In Russian)

Vanke A., Polukhina E. (2014) Vechnyi ogon' v Aleksandrovskom sadu kak publichnoe mesto pamyati. [Eternal Flame in Aleksandrovsky Garden as a Public Site of Memory]. Interaction. Interview. Interpretation, no 8, pp. 36-51. (In Russian)

WCIOM (2013) Simvoly Rossii: narodnyi reiting [Symbols of Russia: The People's Rating]. Available at: http://wciom.ru/index.php?id=459\&uid=114529 (accessed 20 December 2014). (In Russian)

Yin R.K. (1994) Case Study Research Design and Methods, London: SAGE.

\title{
Социальные практики использования мемориалов в России: сравнивая Мамаев Курган в Волгограде и Поклонную гору в Москве
}

\author{
Елизавета Полухина \\ Кандидат социологических наук, доцент факультета социальных наук Национального \\ исследовательского университета «Высшая школа экономики» \\ Адрес: ул. Мясницкая, д. 20, Москва, Российская Федерация 101000 \\ E-mail: epolukhina@hse.ru
}

\author{
Александрина Ваньке \\ Кандидат социологических наук, заместитель декана по научной работе социологического факультета \\ Государственного академического университета гуманитарных наук, научный сотрудник Института \\ социологии Российской академии наук \\ Адрес: Мароновский переулок, д. 26, Москва, Российская Федерация 119049 \\ E-mail: alexandrina.vanke@gmail.com
}

В статье излагаются результаты исследования социальных практик использования мемориалов, посвященных Великой Отечественной войне в постсоветской России. Авторы представляют сравнительный анализ двух кейсов. Они изучают Поклонную гору, расположенную в Москве, которая является местом памяти (lieux de memoir), согласно Пьеру Нора, где не происходили реальные военные сражения во время битвы за Москву в 1941-1942 гг. Этот кейс сравнивается с Мамаевым курганом, расположенным в Волгограде, который является памятным местом (lieux de souvenir), согласно Алейде Ассман, где имели место жесткие сражения во время Сталинградской битвы в 1942-1943 гг. Авторы детально описывают пространственную инфраструктуру обоих мемориалов и выстраивают классификацию практик в отношении их использования, включая коммеморативные, политические, досуговые, религиозные практики, а также практики, связанные с инфраструктурой, применяемые разными группами социальных агентов. Авторы приходят 
к выводу о том, что Поклонная гора - универсальный мемориал, транслирующий монологический героический дискурс, в то время как Мамаев курган воспроизводит такой же триумфальный дискурс, преломленный через локальный контекст интеракций между местными властями и городскими сообществами.

Ключевые слова: военные мемориалы, пространство военных мемориалов, использование военных мемориалов, социальные практики, Поклонная гора, Мамаев курган, Россия 